\title{
IMPACT OF SOCIAL SERVICES PARTICIPATION OF UNDERGRADUATE STUDENTS ON THEIR ACADEMIC ACHIEVEMENT
}

\author{
Goutam Padhan \\ Master of Arts in Education, Gangadhar Meher University, Sambalpur, Odisha
}

Article DOI: https://doi.org/10.36713/epra8295

DOI No: 10.36713/epra8295

\begin{abstract}
The objectives of the study were to investigate the impact of $i$ ) social services participation undergraduate students on their academic achievement; ii) social services participation undergraduate boys students on their academic achievement, and iii) social services participation of the undergraduate girls students on their academic achievement. A sample of 80 undergraduate students of Gangadhar Meher University, 40 each from participants and non-participants students were selected randomly. Out of which 20 each from boys and girls undergraduate students were participants groups and 20 each from boys and girls undergraduate students were from non-participants groups. Information Inventory on Social Service Participation Test was used for data collection and average academic achievement SGPA score of undergraduate students given by university was adopted for accessing the academic achievement of students. The 't' test revealed that i) there was no impact of social service on academic achievements of undergraduate students. Academic achievement of both social service participant and non-participant undergraduate students were similarly; ii) there was no impact of social service on academic achievements of participant and non-participant undergraduate boys students'. Academic achievement of both social service participant and non-participan boys undergraduate students' were same line; and iii) there was no impact of social service on academic achievements of participant and non-participant undergraduate girls students. Academic achievement of both social service participant and non-participant girls undergraduate students' were same line.
\end{abstract}

KEY WORDS: Social Services, Participation, Under Graduate, Academic Achievement

\section{INTRODUCTION}

In our formal education system both curricular and extracurricular experience gain by the students for achieving social and national goal is the central aim of education. It is very much essential to provide such types of experience to students by engaging them with some extracurricular activities. It is the only way to develop a socially accepted personality of all individuals. There are different activities but not mandatory for students such as voluntary works perform by students in educational institution developing their social as well as national aims. At present extracurricular activities organising in institution such as NSS, Scout, JRC, NCC etc. decreasing the anti-social behaviour of the student is the greater achievement of education. It is not only beneficial for the student to develop a socially desirable behaviour, rather societies also benefited by it. It decreases the chances of dropout of the student, explores interest among towards humanities, higher self- esteem, and also develops social interactions as well as some for making students into a complete social being.

\section{RATIONALE OF THE STUDY}

A critical analysis of various studies conducted on social services participation of undergraduate students showed positive impact of co-curricular activities on academic achievement (Wilson, 2009; Steven, 2012; Bashir, 2012; Izam, 2015; Singh, 2017; Nasir et al., 2018), professional ability (Dhanmeher, 2014) and leadership behaviour (Ahmed et al., 2015; Singh, 2017) of students at secondary level. The attitude of boys and girls as well as urban and rural secondary schools students' towards participation in co-curricular activities differs significantly (Ghosal, 2016). Now a day extracurricular activities such as social services 
have been a parameter of students' quality development. It has great importance in achieving social and national goals. A least number of attempts has made towards impact of

\section{OBJECTIVES}

1. To studythe impact of social services participation of undergraduate students on their academic achievement.

2. To study the impact of social services participation of undergraduate boys students on their academic achievement.

3. To study the impact of social services participation of the undergraduate girls students on their academic achievement.

\section{HYPOTHESES}

(i) There exists no significant difference between social service participation of undergraduate students on their academic achievement.

(ii) There exists no significant impact of social service participation of undergraduate boys' students on their academic achievement.

(iii) There exists no significant impact of social service participation ofundergraduate girls' students on their academic achievement.

\section{METHODOLOGY \\ Design}

The investigator was used Ex-post facto research design in the present study as the objectives of the study was to examine the impact of participation in social services of undergraduate students on their academic achievement and social service participation of students is a naturally occurring phenomenon. social services participation of undergraduate students on their achievement, as it is an innovative attempt towards nation building for which the present study has been undertaken Sample

A sample of 80 undergraduate students of Gangadhar Meher University, 40 each from participants and non-participants students were selected randomly. Out of which 20 each from boys and girls undergraduate students were participants groups and 20 each from boys and girls undergraduate students were from nonparticipants groups.

\section{Tools}

Information Inventory on Social Service Participation test developed by investigator was used for data collection and average academic achievement SGPA score of undergraduate students given by university was adopted for accessing the academic achievement of students. The content validity of the test was ascertained by the help of expert judgement and reliability co-efficient of the test was .91.

\section{RESULT}

As can be seen in Table 1 there found out no significant of difference between social service paticipation (participant vs nonparticipant) undergraduate students studying in Gangadhar MeherUniversity, Sambalpur on their academic achievements $(\mathrm{t}=0.77, \mathrm{df}=78, \mathrm{P}>0.01)$. It can be revealed that there was no impact of social service on academic achievements of undergraduate students studying in Gangadhar Meher University, Sambalpur. Academic achievement of both participant and non-participant undergraduate students were similarly (M=7.28 $\geq \mathrm{M}=7.16$ ).

Table-1

Summary of ' $t$ ' value for social services participant and non-participant students of undergraduate students on their academic achievement $(N=80)$

\begin{tabular}{|c|c|c|c|c|}
\hline Category of Undergraduate Students & Mean & SD & 't' values & $\begin{array}{c}\text { Levels of } \\
\text { Significance }\end{array}$ \\
\hline Social Service Participant Student & 7.28 & 1.06 & \multirow{2}{*}{0.77} & NS \\
\cline { 1 - 3 } Social Service non-Participant Student & 7.16 & 0.74 & & \\
\hline
\end{tabular}

Not significant at 0.05 level

*Not significant at 0.01 level

As can be seen in Table 2, there found out no significant of difference between social services participation (participant and non- participant) undergraduate boys students studying in Gangadhar Meher University, Sambalpur on their academic achievements $(\mathrm{t}=$ 
$1.11 ; \mathrm{df}=38 ; \mathrm{P}>0.01)$. It revealed that there was no impact of social service on academic achievements of participant and non-participant undergraduate boys students' studying in Gangadhar Meher University, Sambalpur.
Academic achievement of both participant and nonparticipan boys undergraduate students' were same line $(\mathrm{M}=7.4 \geq \mathrm{M}=7.0)$.

Table-2

Summary of ' $t$ ' value for social services participant and non-participant boys undergraduate students on their academic achievement $(\mathbf{N}=40)$

\begin{tabular}{|c|c|c|c|c|}
\hline Category of Undergraduate Students & Mean & SD & $\begin{array}{c}\text { 't' } \\
\text { value }\end{array}$ & Levels of Significance \\
\hline Participant boys student & 7.412 & 1.31 & \multirow{1}{*}{$\mathbf{1 . 1 1}$} & N.S. \\
\hline Non-participant boys Student & 7.004 & 0.73 & & \\
\hline
\end{tabular}

*Not significant at 0.05 level

*Not significant at 0.01 level

As can be seen in Table 3 there found out no significant of difference between social services participation of (participant and nonparticipant) undergraduate girls students studying in Gangadhar Meher University, Sambalpur on their academic achievements $(\mathrm{t}=$ $0.83 ; \mathrm{df}=38 ; \mathrm{P}>0.01)$. It revealed that there was no impact of social service on academic

Table-3

Summary of ' $t$ ' value for social services participant and non-participant girl undergraduate students on their academic achievement $(\mathbf{N}=40)$

\begin{tabular}{|c|c|c|c|c|c|}
\hline Category of Undergraduate Students & Mean & SD & df & $\begin{array}{c}\text { 't' } \\
\text { value }\end{array}$ & Level of Significance \\
\hline Participant girls student & 7.15 & 0.75 & 38 & 0.83 & NS \\
\cline { 1 - 3 } Non-participant girls student & 7.31 & 0.74 & & & \\
\hline
\end{tabular}

*Not significant at 0.05 level *Not significant at 0.01 level

\section{MAJOR FINDINGS}

1. There was no impact of social service on academic achievements of undergraduate students. Academic achievement of both social service participant and nonparticipant undergraduate students were similarly.

2. There was no impact of social service on academic achievements of participant and non-participant undergraduate boys students'. Academic achievement of both social service participant and non-participan boys undergraduate students' were same line.

3. There was no impact of social service on academic achievements of participant and non-participant undergraduate girl students. Academic achievement of both social service participant and non-participant girls undergraduate students' were same line. achievements of participant and non-participant undergraduate girls students studying in Gangadhar Meher University, Sambalpur. Academic achievement of both participant and nonparticipan boys undergraduate students' were same line $(M=7.15 \leq M=7.31)$

\section{DISCUSSION AND CONCLUSION}

The findings revealed that social services have no impact on academic achievement of participant and non-participant undergraduate students. It shows that both participant and non-participant undergraduate students have been secured satisfactory grades. Participation of undergraduate students in social services has motivated to achieve their goals as well as service for mankind. Whereas, non-participant undergraduate students focusing on achieving educational goals. Students' participation in social services does not hamper in their academic progress because students are engaging social services after the class and leaser time. They used holidays for their social services. However, it can be concluded that social service participant undergraduate students and non-participant undergraduate students were not different in their cognitive development as well as academic achievement. 


\section{REFERENCES}

1. Ahmad,M., Rahman,F. \& Azad, M.(2015). Effect of extra-curricular activity on students' academic performance. Journal of Armed Forced Medical College, 11(2), 41-46.

2. Bashir, Z. (2012). The effectiveness of cocurricular activities on academic achievement of secondary school students in district Abbottabad, Pakisan: A case Study. Developing Country Studies, 2(2), 53-58.

3. Dhanmeher, B. R. (2014). Impact of cocurricular activities on the non academic development of junior school students. Master of Philosophy dissertation, D. Y. Patil University.

4. Izam, S. and Esa, A. (2015) Effect of cocurricular activities on academic achievement of education students with learning disability. Elixire. Social Science, 89, 36980-36983.

5. Muhammad,D., Hassan,A., Nawaz,T., Hasan, A., \& Mubeen, I. (2012). The effect of cocurricular activities on the academic performances of students.Bulgarian Journal of
Science And Education policy, 6(2),257- 272.

6. Nasir, A., Muhammad, A., Rahmat, U. S., Abdul, B.K., Ahmad, T. \& Gul, A.K. (2018). Impact of co-curricular activities on students' academic achievement at secondary school level. Journal Institute of Education and Research, 30 (1), 63-66.

7. Singh, A. (2017). Effect ofcocurricular activitieson academic achievement of students. International Journal of Education and Social Science, 17(1), 73-82..

8. Steven, C.(2012). The impact of extracurricular activities on the student achievement at the highschool level. The Aquila Digital Community, Dissertation, University of Southern Mississippi.

9. Wilson,P.(2009). Impact of extracurricular activities on the student. Dissertation of M.Sc, American Psychological Association, University ofWisconsin-Stout. 